\title{
Digital Anti-Corruption Tools and Their Implementation in Various Legal Systems Around the World
}

\author{
Andrii Halai ${ }^{1}$, Viktoriia Halai $^{2}$, Roksolana Hrechaniuk ${ }^{3}$, and Kateryna Datsko ${ }^{2 *}$ \\ ${ }^{1}$ Member of the Board of the Association of Legal Clinics of Ukraine, Ukraine \\ ${ }^{2}$ State University of Economics and Technology, Ukraine \\ ${ }^{3}$ West Ukrainian National University, Ukraine
}

\begin{abstract}
Just as there is no ideal society, there is no society without corruption. Fighting corruption is one way to achieve the UN-approved goals of sustainable development. The article summarizes the process of formation and implementation of international anti-corruption standards and their features in different national legal systems. It is determined that the adoption and recognition of standards does not in itself solve the problem, which is why the world is constantly looking for ways to combat corruption, testing new tools and mechanisms to influence corruption risks. This is confirmed by numerous projects funded by international donor organizations. Information technologies create endless opportunities not only for economics development (robotics, blockchain technology, neural networks, artificial intelligence, quantum virtual and augmented reality), but also for the fight against corruption: from e-government and courts, digital public services and tools that report about the facts of corruption, to the means of influencing society through social networks. The article analyzes scientific and professional research in the field of digitalization of anti-corruption activities and substantiates the relationship of these concepts from the standpoint of the impact of IT technologies on combating and preventing corruption. The article summarizes modern technological advances and their implementation in various national legal systems, defines the role of information technology in the fight against corruption and forms an understanding of information technology as a tool to control and combat corruption.
\end{abstract}

\section{Introduction}

Corruption is already recognized as one of the main problems of the world economy. According to the UN, the annual amount of bribes worldwide is $\$ 1.6$ trillion. At the same time, the world economy is losing another $\$ 2.6$ trillion due to corrupt activities, which account for 2.7 percent of world GDP [1].

EU Commissioner for Home Affairs Cecilia Malström said in a 2014 report that corruption cost the European economy around $€ 120$ billion a year. These calculations are based on a study of data on corruption in $28 \mathrm{EU}$ member states [2].

Corruption is a multifaceted phenomenon that should be considered from a legal, economic, political, sociological and even psychological point of view.

A number of studies conducted by the World Bank have examined the relationship between the effectiveness of combating corruption and the development of digital technologies. These studies point to the positive impact of increasing government transparency and the quality of public services and the negative impact of political processes in the country, for example, during the election period, when voters are influenced through social networks and the uncontrolled process of collecting personal data.

Modern scientific and specialized research on ways and methods of combating corruption is based on fundamental research on the concept of corruption and the factors that affect it.

The work of scientists who laid the foundation for the study of corruption at the professional level is devoted to the essence of corruption, the historical background of its emergence, its philosophy and impact on society. Among them we can specify the works of Klitgaard, R., Friederich, C., Huntington, S.

Back in 1988, the American economist Robert Klitgoard summarized the factors that stimulate corruption in the already known "formula of corruption":

$$
\begin{aligned}
& \text { Corruption }=\text { Monopoly }+ \text { Freedom of Action - } \\
& \text { Accountability }
\end{aligned}
$$

In his study, he investigated and proved the destructive effects of corruption and demonstrated how bribery, extortion, fraud, kickbacks and conspiracies have led to backward economies, uncontrolled oligarchic influence and political instability [5].

The above formula of corruption illustrates and makes it possible to analyze the degree of influence of various factors on the process of preventing and combating corruption, in particular when looking for effective tools in anti-corruption work 


\section{Recognition of the destructive impact of corruption in the world's legal systems}

In legal systems, corruption is a crime. The start of international recognition of combating corruption took place in 1975, when the world economy entered a new stage of development and rapid growth of transnational corporations. It was then that the Resolution against Corruption was adopted, which is practiced by transnational and other corporations. This document called on the governments of all countries to take the necessary measures at the national level to prevent and combat corruption.

Later, the world will determine the need to criminalize corruption and establish strict accountability for its manifestations.

A significant international achievement in the fight against corruption has been the adoption of the UN Convention against Corruption by the United Nations General Assembly. This document laid the foundation for most national laws around the world. As of 2019, the Convention has been ratified by 186 countries.

The document is not binding, i.e. a country will not be sanctioned for non-compliance with the Convention and to be obliged to comply with it. But the Convention sets common standards of conduct and work standards of government that will help combat corruption in the country.

The UN Convention does not define corruption, but defines standards of conduct, signs of modern governance and contrasts them to corruption, promotes common principles: honesty, transparency, impartiality of government.

Corruption is a worldwide problem, and the world did not immediately realize its devastating impact. For example, the corruption scandal with the private company Enron, which deceived key partners whose shares on the stock exchange were overvalued because they published distorted financial statements. For its operations, Enron created, according to various estimates, about 600-700 companies located in offshore areas located in the United States and on the islands. For many years, they had an auditor who turned out to be corrupt. This audit firm, which no longer exists after this major corruption scandal, was closed (USA, 2002) [3].

The scandal helped the United States completely overhaul anti-corruption legislation, and in 2002 a new law was passed, the Sarbanes-Oxley Act, which tightened liability for corruption and financial fraud.

2014 marked the beginning of the struggle for development, economic growth and overcoming corruption in Ukraine. National anti-corruption legislation was initiated in the wake of the resonance of the events of the Revolution of Dignity in 2014, which revealed numerous corruption risks in the country. The Law of Ukraine "On Prevention of Corruption" was adopted with the involvement of the public opinion, based on international standards and the peculiarities of the national legal system. Today, the country has a well-developed anti-corruption structure, and at the same time, numerous problems in its work due to lack of transparency of the government and evolutionary unwillingness to recognize some activities as corruption, uncontrolled funding of political parties and, consequently, their impact on anti-corruption bodies.

The world did not immediately understand the importance of fighting corruption, and so International Anti-Corruption Standards have come a long way, based on numerous corruption scandals and a gradual understanding of the need to criminalize corruption.

It is advisable to conduct a critical analysis of global corruption research conducted by relevant anticorruption organizations and the world scientific community.

Profile NGOs investigate corruption at the level of global sociological and analytical research. Experts from the world's most authoritative anti-corruption organization, Transparency International, say: "To sweep away corruption, we must first understand it. That is why we investigate what exactly causes corruption and what acts against it" [4].

Transparency International assesses corruption by calculating the annual Corruption Perceptions Index (CPI) and classifies countries and territories by perceptions of the level of corruption in the public sector. CPI is the most well-known indicator of corruption worldwide. The index assesses corruption only in the public sector, identifying one of the main reasons for the corruption development - lack of control over the financing of political parties, reduced transparency of public administration and the process of providing public services. The calculation of the Index is based on 13 surveys of relevant organizations, including a survey conducted by the World Bank and the International Monetary Fund.

Such studies are a tool for both the government and the professional community, as their results provide an opportunity to assess the effectiveness of anticorruption work and the tools involved at the national level.

\section{The impact of digitalization on anti- corruption processes}

Digitalization is the introduction of digital technologies in all spheres of public life: from the usual communication between people to the development of high-tech enterprises, it is the transition from the real to the virtual world, the so-called online world.

The influence of digital technologies is felt in all areas, as confirmed by modern researchers.

The world of digital technologies, which we enter, is not only a new logical stage in the development of the technological sphere of mankind, but also the entire existing legal and socio-political reality. There are no generally accepted and harmonized definitions and legal definitions yet, but digital technologies are already rapidly capturing bridgeheads for the attack. Digitalization is becoming the most important factor in the economic growth of any country's economy and in general is a modern trend [6]. 
The development of IT technologies often occurs during global crises. In particular, due to the global pandemic of COVID-19 a variety of electronic services and tools for communication, education and even the provision of medical services has rapidly developed. In response to the health emergency, governments have introduced new tools, such as COVID-19 special information portals, hackathons, electronic medical supplies, virtual medical consultations, self-diagnosis programs, and more.

Many countries have rapidly deployed distance learning programs as well as home schooling.

The rapid development of digital technologies is creating not only positive changes, but also increasing risks for the legal systems and security of states.

The World Bank has assessed the challenges governments are facing in fighting corruption. The report of this study emphasizes that as a result of the global COVID-19 pandemic, billions of dollars are borrowed and spent by countries, bypassing standard accountability procedures to manage the COVID-19 situation, leading to an increased risk of corruption. To promote greater accountability, governments need to articulate their actions, apply rules, address violations, and cope with the issues of transparency as soon as possible. The main tools of fiscal transparency, citizen involvement and social responsibility are becoming increasingly important [7].

Expert on social programs O. Pyshchulin from the Ukrainian Center for Economic and Political Studies named by $\mathrm{O}$. Razumkov identifies the following threats to digitalization:

- the possibility of concentrating power in the market and strengthening monopolies;

- capture of new markets by transnational corporations;

- destabilization of the monetary system;

- increasing dependence on leading companies in the field of information and communication technologies [8].

These threats are factors that increase the corruption risks of the state, because the creation of monopolies increases market control by individual companies, reduces competition, promotes the development of the oligarchic class and, accordingly, influence on political parties and government everything abovementioned is considered corruption risks. That is why these risks should be taken into account for developing or transition countries, despite the fact that digitalisation contributes to the development of the economy, and thus the living standards of citizens.

The impact of digitalization on the fight against corruption is unclear, the threats and factors that may contribute to the growth of corruption risks of the state require separate studies of the potential impact of digitalization on the perception of corruption and the effectiveness of IT technologies in combating it.

In 2018, the Latin American Conference discussed mechanisms to reduce corruption and restore public confidence in public institutions, including the automation of service delivery processes, governance and accountability.
"The digital revolution is not only a revolution of the economy, but also of the state. Latin American society is becoming younger, more urbanized and more united, and this transition offers countless opportunities to use the digital world and adapt institutions to the demands of civil society," said Carlos Santiso, Director of Digital Innovation at CAF (Latin American National Development Bank).

The African authorities already recognize that corruption is a constraint on the achievement of the Sustainable Development Goals, and at the same time makes it impossible to overcome poverty, high child mortality and hunger. In 2020, the IMF's African Department conducted a global empirical study in 26 African countries, surveying 23,000 people and examining the impact of digitalization on perceptions of corruption in the country and trust in Africa's tax authorities [9].

Today, the African government has high hopes for IT technologies that reduce the human factor in the delivery of public services, as it promotes transparency of government and the civil service as a whole.

The results of the study indicate that the use of digital technologies helps to create direct and more transparent channels of communication between a civil servant and a citizen of the country. The results of the study also touched upon the impact of the Internet on the perception of corruption. This part of the study indicates that the population trusts the government more when it has free access to the network (during 2020, African countries systematically blocked the Internet for the population).

The use of information technology helps to increase perceptions of corruption, trust in government and can suggest new tools to increase government transparency and prevent corruption.

\section{World experience in the use of IT technologies to combat and prevent corruption}

The main goal is to automate standard, paper, outdated systems and operations used to interact with citizens. This should make public services open, accessible and convenient for citizens.

International experience already has a number of digital solutions, the use of which helps to ensure transparency, openness of government and equal access to public services for the population

\subsection{E-government and convenient government services}

The level of development of e-government in the world is assessed by the United Nations Department of Economic and Social Affairs (UNDESA) since 2003 according to the EGDI (EGovernment Development Index), which is conducted every two years. The EGDI index is a comprehensive indicator that combines three sub-indices - online services, telecommunications infrastructure, human capital and is used to measure the readiness of governments to use information and 
communication technologies to provide quality information and public services to the people, business and their use in the work of the authorities themselves [10].

In addition to the e-government development index, the EGDI uses the EPI (EParticipation Index), which is based on three components: e-information, econsultation and e-decision-making, to assess the provision of interactive information services to citizens. On the top of the ranking of 193 UN member states on the level of digital government by 2020 , taking into account the volume and quality of online services, the state of telecommunications infrastructure and existing human potential, are Denmark, the Republic of Korea and Estonia, followed by Finland, Australia, Sweden, UK, New Zealand, the United States, the Netherlands, Singapore, Iceland, Norway and Japan.

Among the least developed countries, Bhutan, Bangladesh and Cambodia have become leaders in the development of digital government, moving from the middle to the highest group of the e-government development index (EGDI) in 2020. Mauritius, Seychelles and South Africa are on the top of the government ranking in Africa. Overall, 65 percent of Member States are at a high or very high level of EGDI [11].

Latin American countries are characterized by an overly bureaucratic process of public service delivery and a high level of corruption. According to Transparency International, in 2017, 30\% of Latinos paid a bribe for access to public services, which is almost 30 million people in the region. Such indicators have helped to find new solutions that already have a positive impact.

For example, Mexico, Peru, Brazil and Argentina are already united in the process of improving the system of public access to quality public services. These countries have introduced integrated portals to a number of public services. That is, the population already has the opportunity to register a number of services online. However, online service delivery rates are low. This activity was investigated by the Wait no more project [12]. The $2018 \mathrm{draft}$ report indicates that, despite significant efforts, the process is being hampered by the fact that not all civil servants and government officials are ready for such changes. Some of them are afraid of losing their jobs, others - of losing systemic income from illegal benefits in the process of providing public services.

On January 01, 2019, the Order of the President of Argentina came into force, which introduces the socalled e-government or "paperless government". The order came into force gradually, and government agencies were given a year to train and translate a number of procedures online. To implement it, the government has trained 227,900 users of the new system.

Portugal, which has introduced e-government through the Simplex program, has a successful experience [13]. The country uses this tool to modernize the process of providing public services, increase openness and facilitate the interaction of legal entities and individuals in obtaining public services. Experts acknowledge that the success of this program is based on the fact that it is constantly being improved through discussions with the public and relevant organizations. The program's website has a window for public appeals with suggestions, recommendations and comments, which gives the opportunity for everyone to be heard. This process puts the citizen at the center of public services, forms in them an understanding that their voice is heard and gradually changes the psychology of civil servants.

A similar approach to de-bureaucratization of public services has been introduced in Brazil since 2017, where the program "sSimplifique!" is functioning [14].

Countries that are on the path of civil service and judicial reforms are also hoping to digitize processes and eliminate the influence of the human factor in the quality, speed and accessibility of public services. Ukraine has been actively starting the reform process since 2014. Such work has been introduced at the system level since 2016, when Ukraine approved the Digital Agenda of Ukraine until 2020. In 2019, the Ministry of Digital Transformation was launched in the country. The strategic goals until 2024 are to ensure the availability of $100 \%$ of public services for citizens and businesses online.

Today, the country's public services portal Diya is already operating in the country. The portal makes it possible to register a number of services online for citizens (benefits, certificates, registration of a child in kindergarten, etc.) and for business (business registration, business closure, reporting, ordering certificates). At the same time, the problem remains that not everyone is ready to use such services as citizens and civil servants. Therefore, the queues in the departments of social protection, unfortunately, are still maintained.

Successful practices for such improvements in public service delivery already exist in the following countries: the United Kingdom, France, Canada and Israel. The results of the work of governments in this direction were presented at the summit of state technologies [15].

We believe that the spread of such practices can contribute to the development of interesting startups and create competition for the state in providing relevant services. And competition is a factor in economic development, and hence the path to quality public services for citizens.

The list of successful cases of countries that have recently begun their path of automation of public services can be continued. All decisions differ in terms of implementation, number and characteristics of the country's population, features of the political and economic situation in the countries and the level of technology development. However, the implementation of such decisions is a step that changes the consciousness of citizens and civil servants themselves. 


\subsection{Use of open data}

Open data can increase the transparency of government by disclosing data on budget procurement, land ownership, education and medicine, crime statistics, financial reports of government agencies and the state, government contracts, international procurement, environmental statistics and more.

At the international level, the process of introducing open data by governments is regulated by the International Open Data Charter. The Charter is an international initiative that promotes cooperation, the adoption and implementation of common principles, standards and best practices for the disclosure and use of open data around the world.

The public is also working to develop and promote open government data. The World Wide Web has created the Open Data Barometer, which summarizes the Global Indicator of How Governments Publish and Use Open Data for Accountability, Innovation, and Social Impact.

Among the tools to combat corruption of the anticorruption NGO Transparency International is the maintenance of a register of unscrupulous participants in public procurement, February 2013 [17].

The greatest positive effect from the introduction of information technology was observed in the UK, Canada, France and the USA. Sweden, Denmark, Korea, and Japan were in the top ten. These are countries that also have a high level of technology development and the Corruption Perceptions Index, according to Transparency International research.

At the same time, countries with significant problems in terms of integrity and achieving the Sustainable Development Goals have a positive impact on the introduction of IT in the public sector.

For example, Mexico has expanded the breadth and depth of open budget data through its state-of-the-art portal on financial transparency, which includes public procurement and infrastructure investment. Mexico City became the first city to present its purchases in an open format. In turn, relevant NGOs use this information to study government and raise red flags to uncover once-hidden practices and patterns.

According to O.V. Altsyvanovych and Ya.Yu. Tsymbalenko, deserves attention in the US and EU eprocurement and electronic reporting on public procurement, where the e-procurement system is considered a tool that increases accountability and transparency in public administration [18].

The use of open data has made it possible to establish a transparent public procurement process in a number of countries. A successful case is currently working in Ukraine. Starting the Prozzoro system. The efficiency of the software product in 2020 indicates that the country has saved UAH 43 billion in Prozorro tenders and earned UAH 11 billion in Prozorro auctions [19].

Similar software tools have been introduced in Romania, Spain, and Brazil during public procurement of medicines.
Open data ensures transparency of government and, accordingly, helps reduce the level of corruption risk of the state and civil servants; expanding opportunities for business development and participation in government procurement, and consequently increasing competition in the market of goods and services

\subsection{Use of blockchain technologies in the fight against corruption}

Blockchain technologies alone are difficult to imagine as a tool in the fight against corruption, but their current use raises hopes that they can provide an asset tracking process and control government contracts. However, there are legal problems with the use of blockchain technology and its impact on public relations.

Research on the impact of blockchain on social change is also the subject of attention of relevant organizations. As a tool for resolving information asymmetries, Blockchain may be able to empower people who do not have sufficient services and help to solve societal problems. This study was conducted as part of the BLOCKCHANGE project [20]. The project explored the impact of blockchain technologies on the social sphere in three areas: human resources, logistics, contracting and public services.

In 2018, the National Research Council of Canada (NRC) began piloting a new blockchain based on Ethereum for more open public procurement administration. For example, Canadians can obtain government funding data through this smart contract.

With blockchain technology, India has improved the process of tracking land ownership by combining technology with land registries. Switzerland is improving access to public services. And in the United States, electronic voting in elections is already underway.

All of these processes are closely linked to the collection and transfer of personal data, so in addition to the benefits, there can be challenges for the entire system that involve identity theft, cybercrime and fraud.

\subsection{Use of IT technologies in the work of anti- corruption bodies}

Anti-corruption infrastructure exists in every country in the world. However, in different countries its structure, influence of power, methods of work and responsibility for corruption offenses are different. It depends on the level and perception of corruption in the country, the will of the top leadership of the state, the degree of public involvement in the work of anti-corruption bodies and, in particular, the level of digitalization of a number of processes in the state.

For example, in Denmark, which has a relatively low level of corruption and a high Corruption Perceptions Index, no anti-corruption body has been created, but criminal liability has been established for corruption offenses. A similar example is Finland, which also holds some of the highest positions in anti- 
corruption rankings. This country also does not have a developed anti-corruption infrastructure. Germany, France, Italy have more developed anti-corruption structure, these countries due to their historical features (development of mafia groups, business that conducts extensive international activities) at due time, were forced to take drastic measures and increase the level of anti-corruption bodies. Today, the countries are an example of a fairly successful experience in the fight against corruption.

The basic principles on which governments base their fight against corruption are:

- transparency of the public sphere;

- control over the financing of political activity;

- personal civic activity.

All these principles will be able to work effectively only with the digitalization of individual processes. Of course, countries that are leaders in the development of IT technologies have introduced electronic registers, egovernment, e-court long ago. Their effectiveness has already been proven.

Let us consider the successful practices of involving IT technologies in the work of anticorruption bodies, in the countries that are at the stage of formation of the fight against corruption.

Ukraine's experience shows that the adoption of anti-corruption legislation and the launch of anticorruption infrastructure is not enough for its effective operation. Together with the factors of influence of power and level of competence of employees of anticorruption structures, such structures work more effectively when they involve IT technologies that process large amounts of data, provide services for public information on successful cases of the body, allow to receive reports of corruption offenses, etc. The country has already launched the following technological solutions to improve anti-corruption work: public Unified State Register of Declarations of Persons Authorized to Perform State or Local SelfGovernment Functions (for submission, verification and analysis of information on persons whose activities are subject to declaration); the electronic register of financial statements of political parties is already working in test mode; the Unified State Register of Persons Who Have Committed Corrupt or CorruptionRelated Offenses has been launched. Strategic plans also include the launch of an anti-corruption portal and the further development of open data on anticorruption structures.

In Slovenia, the electronic register of declarations was launched in 2011, and from this time declarations can be made online. For example, in Macedonia there is also an electronic register, but declarations are still submitted on paper. Through the relevant websites of anti-corruption structures in the country, online training of target groups of the public and civil servants is conducted.

Through official websites and social networks, anticorruption bodies around the world carry out educational work with the population and organize online training for civil servants.

Information technologies have a significant impact on ensuring effective work with whistle-blowers, because in this part it is necessary to ensure reliable protection of communication channels, anonymity of the user and at the same time effective communication to verify the received information.

\section{Conclusion}

Technology is becoming a key ally in the fight against corruption. New technologies and open data now allow anti-corruption people to detect, prevent and even predict corrupt practices that in the past could have been hidden behind a curtain of paper document opacity.

Technology is becoming a reliable ally of governments seeking to combat corruption, because combined with their political will, technology can change the policy-making process of public service delivery. Digitalization allows states to establish effective anti-corruption bodies and adapt to the requirements of the digital society and achieve the goals of sustainable development.

The introduction of anti-corruption tools in the digital world is impossible without the openness of governments, free access to networks and, consequently, information from state institutions, which, in our opinion, will build public confidence in government and improve the quality of public services.

At the same time, their implementation should take into account a number of features of each country and factors that directly or indirectly affect the effectiveness of the use of IT technologies. The study of anti-corruption experience of countries in different legal systems of the world makes it possible to form a list of factors that should be taken into account when implementing the relevant systems. After all, sometimes such tools can become a tool in the hands of corrupt government officials or government officials. That is why it is important to assess national anticorruption strategies, features and degree of digitalization of other related processes, the level of skills of performers and the population in the use of information technology, public support.

The study also pointed to the need for constant dialogue with relevant NGOs to improve such systems and find new technological solutions to prevent, combat corruption and develop quality public services.

Thus, among the digital means of combating corruption in the studied legal systems of the world the following ones can be distinguished:

1) creation of an e-government system;

2) provision of digital public services with the use of information and communication technologies;

3) creation of tools to detect manifestations of corruption, including: e-declaration, electronic bidding for public procurement, electronic reporting;

4) use of social networks to detect cases of corruption in the public sector;

5) use of the Internet for free access to public information and the opportunity to obtain the necessary information on the activities of public bodies, through open access, e-mail, etc. 


\section{References}

1. UN: Hundreds of Billions of Dollars Lost to Governments Due to Financial Crime that could be spent on social development (2020) URL: https://news.un.org/ru/story/2020/09/1386622

2. Štefan Šumah Corruption, Causes and Consequences (2018) URL: https://www.intechopen.com/books/trade-andglobal-market/corruption-causes-andconsequences

3. Demonstrative collapse: how the history of the American Enron reshaped the corporate legal field of the world (2008) URL:

https://mind.ua/publications/20183712-pokazovijkrah-yak-istoriya-amerikanskoyi-enronperekroyila-korporativne-pravove-pole-svitu

4. Research. To end corruption we must first understand it. That's why we look at what causes corruption and what works against it. URL: https://www.transparency.org/en/research

5. Klitgaard, R. Controlling Corruption. University of California Press (1988)

6. Sosnin O. Digitalization as a new reality of Ukraine. Legal Bulletin of Ukraine (2020) URL: https://lexinform.com.ua/dumkaeksperta/tsyfrovizatsiya-yak-nova-realnistukrayiny/

7. Sasana Kijang, Jalan Dato Onn, Kuala Lumpur Enhancing Government Effectiveness and Transparency The Fight Against Corruption, Malaysia (2020)

8. O. Pushchulina Two sides of digital technologies: "digital dictatorship" or maintaining stability. (2019)

9. Rasmane Ouedraogo and Amadou N.R. Sy IMF Working Paper African Department Can Digitalization Help Deter Corruption in Africa? (2020) URL:

https://www.imf.org/en/Publications/WP/Issues/20 20/05/29/Can-Digitalization-Help-DeterCorruption-in-Africa-49385

10. E-Governance for Accountability and Participation (EGAP) (EGAP). URL: https://egap.in.ua/en/

11. United Nations E-Government Survey (2020) URL: https://publicadministration.un.org/egovkb

12. Benjamin Roseth, Angela Reyes, Carlos Santiso Cataloging-in-Publication data provided by the Inter-American Development Bank Felipe Herrera Library, USA (2018)

13. Simplex. Official site URL: https://www.simplex.gov.pt/livro

14. Simplifique. Official site URL: http://www.simplifique.gov.br/

15. E-govtech summit 2020. Official site URL: https://www.govtechsummit.eu/agenda

16. The Open Data Barometer Official site URL: https://opendatabarometer.org/?_year=2017\&indic ator $=\mathrm{ODB}$
17. Anastasia Kalinina Corruption and public procurement: international legal instruments. Adviser in the field of public procurement (2015) URL: https://radnuk.com.ua/zhurnaly/koruptsiiata-derzhavni-zakupivli-mizhnarodni-pravoviinstrumenty-2/

18. Altsivanovich, Ya.Yu. Tsymbalenko Ya. Yu. International and European experience of avoiding corruption risks during public procurement. Aspects of public governance. № 10. V. 6. P.6273. (2018)

19. Ukraine saved UAH 43 billion in Prozorro tenders and earned UAH 11 billion in Prozorro auctions. Sales in 2020. (2020) URL: https://prozorro.gov.ua/news/-ukrayinazaoshchadyla-43-mlrd-grn-na-tenderah-uprozorro-i-zarobyla-11-mlrd-grn-na-aukcionahprozorroprodazhi-u-2020-roci

20. Blockchain for social change. Official site of the project URL: https://blockchan.ge/ 